\title{
Impact of Some of the Important Insecticides on Final Seed Yield of Bell Pepper (Capsicum annuum L.)
}

\author{
Har Lal Meena ${ }^{1}$, Kiran Rana ${ }^{2 *}$, D. K. Mehta ${ }^{3}$, Manohar Lal ${ }^{1}$, Rajesh Kanwar $^{1}$
}

${ }^{1}$ Dept. of Seed Science and Technology, ${ }^{2}$ Dept. of Entomology, ${ }^{3}$ Dept. of Vegetable Science, Dr. Y. S. Parmar University of Horticulture and Forestry, Nauni, Solan, Himachal Pradesh (173 230), India

\section{Corresponding Author}

Kiran Rana

e-mail: kiranuhf@gmail.com

\author{
Article History \\ Article ID: 3 C0506 \\ Received in $13^{\text {th }}$ October, 2017 \\ Received in revised form $07^{\text {th }}$ August, 2018 \\ Accepted in final form $16^{\text {th }}$ August, 2018
}

\begin{abstract}
The present studies were carried out at Department of Seed Science and Technology, Dr. Y. S. Parmar University of Horticulture and Forestry, Nauni, Solan, Himachal Pradesh, India during kharif season 2013 to see the impact of some of the important insecticides on final seed yield of bell pepper (Capsicum annuum L.) cultivar Solan Bharpur. The treatments comprised of seed application of imidacloprid (Gaucho 600FS) and thiamethoxam (Cruiser 70WS), soil application of neem cake@ 2 q acre ${ }^{-1}$ and Carbofuran @ 6 kg acre $^{-1}$ and foliar spray of imidacloprid (Confidor $200 \mathrm{SL}$ ), thiamethoxam (Actara 25 WS), indoxacarb @ 0.5 ml l-1, NSKE (neem seed kernel extract) 5\%, neem formulation @ $2.5 \mathrm{ml} \mathrm{l}^{-1}$ and control condition (without any spray). The observations included number of seeds fruit ${ }^{-1}$, thousand seed weight $(\mathrm{g})$, seed yield plant $\mathrm{t}^{-1}(\mathrm{~g})$, seed yield plot $^{-1}(\mathrm{~g})$ and seed yield ha-1 $(\mathrm{kg})$ and also the benefit: cost ratio was worked out. The result revealed that treatment combination viz., seed treatment and foliar spray with thiamethoxam recorded significantly higher number of seeds fruits ${ }^{-1}$ (190.66), 1000 seed weight (5.58 g), seed yield plant ${ }^{-1}(18.91 \mathrm{~g})$, seed yield plot ${ }^{-1}(385.81 \mathrm{~g}$ ), seed yield ha ${ }^{-1}(714.46 \mathrm{~kg})$ and benefit: cost ratio (4.52:1). Thus thiamethoxam, both as seed treatment and foliar spray may be recommended for insect free higher seed yields of bell pepper.
\end{abstract}

Keywords: Bell pepper, benefit:cost ratio, seed yields

\section{Introduction}

Bell pepper (Capsicum annuum L.) commonly as "Shimla Mirch", "Sweet pepper" or "Capsicum" is an important warm season solanaceous vegetable crop grown almost all over the globe. It finds an important place in the kitchens due to its mild pungent flavor and holds a high nutritional value, particularly of vitamin-C and vitamin-A (Vyrodova et al., 1988) and also rich in minerals like iron, potassium, calcium, magnesium, phosphorus etc. (Agarwal et al., 2007). It is also an important ingredient of modern days' fast foods.

Capsicum is Maxican in origin with its secondary centre of origin in Guatemala (Bukasov, 1930; Smith and Heiser, 1957) and was introduced in India by the English people in the $19^{\text {th }}$ century in Shimla hills. In India, bell pepper is commercially grown in Himachal Pradesh, Jammu and Kashmir, Uttrakhand, Arunachal Pradesh and Darjeeling district of West Bengal during summer months and as autumn crop in Maharashtra, Karnataka, Tamil Nadu and Bihar. The mid hills of Himachal Pradesh are blessed with the climate suited for off season cultivation of bell pepper. Recently in Himachal Pradesh, coloured capsicums like yellow and red have also been introduced which are being cultivated under green houses and the area under the cultivation of this crop is increasing progressively because high market price is attributed to the heavy demand from the urban consumers. There is a high national and international demand of capsicum but supply is inadequate due to low productivity of the crop (Brandt and Mabgaard, 2001).

Seed is the primary and most important input in agriculture which act as catalyst $t$ realize the potential of other inputs such as fertilizers, water etc. and further determines the final agricultural yields. In bell pepper like other vegetables, the seed yield and yield attribute are mainly influenced by various biotic and abiotic factors. Among the biotic factors insect pests are important which cause heavy loss to the crop of which sucking pests and fruit borers which not only affect the seed yield but the seed quality is greatly hampered. They feed on the plant photosynthates, necessary for plant growth and development. Plant protections measures such as seed treatment, soil application and foliar spray when taken up to manage these pests, enhance the seed yield. Although chemical control of various insect pests of bell pepper for 
vegetable production is well documented yet very meager studies on seed treatment, soil application with synthetic insecticides and the use of botanicals for the management of insect pests and their effect on seed yield are carried out in Himachal Pradesh and elsewhere in India. In view of this the present studies were planned to know the impact of some of the insecticides on seed yield of bell pepper.

\section{Materials and Methods}

The present investigations were carried out at Khaltoo Experimental Farm and Laboratory of Department of Seed Science and Technology, Dr. Y. S. Parmar University of Horticulture and Forestry, Nauni, Solan, Himachal Pradesh, India during kharif season 2013. The seedlings of bell pepper var. Solan Bharpur were transplanted as per the treatments in a plot having size of $5.4 \mathrm{~m}^{2}\left(2.40 \times 2.25 \mathrm{~m}^{2}\right)$ in Randomized Complete Block Design with three replicates. FYM and fertilizers were applied as per package of practices for vegetable crops, Directorate of Extension Education, Dr Y S Parmar University of Horticulture and Forestry, Nauni, Solan (HP) (FYM @ 200 q ha ${ }^{-1}$, CAN @ 400 Kg ha-1 $^{-1}$ SSP @ 475 $\mathrm{Kg} \mathrm{ha}^{-1}$ and MOP @ $\left.90 \mathrm{Kg} \mathrm{ha}^{-1}\right)$. The treatments comprised of following treatments having 24 different combinations.

\subsection{Seed treatment}

100 grams of each seed sample was subjected to two seed treatments viz., $\mathrm{S}_{1}$ (Imidacloprid-Gaucho 600FS) and $\mathrm{S}_{2}$ (Thiamethoxam-Cruiser 70WS). The mixture was shaken and kept for 3 days before sowing.

\subsection{Soil treatment}

Neem cake and carbofuran were applied directly to the prepared plots in the field @ 270 g plot $^{-1}$ (13.5 g plant $\left.^{-1}\right)$ and $8.1 \mathrm{~g} \mathrm{plot}^{-1}\left(0.405 \mathrm{~g} \mathrm{plant}^{-1}\right)$ respectively at the time of seedling transplantation.

\subsection{Foliar spray}

The growing crop in the field was sprayed with five foliar solution as per treatment combination per replication first at 30 days after transplanting and second at 15 days after the first spray. The foliar treatment consist of viz., $F_{1}$ (Imidacloprid) @ $0.5 \mathrm{ml} \mathrm{l}^{-1}, \mathrm{~F}_{2}$ (Thiamethoxam-Actara $25 \mathrm{WS}$ ) @ $0.40 \mathrm{ml} \mathrm{l}^{-1}$, $\mathrm{F}_{3}$ (Indoxacarb) @ $0.5 \mathrm{ml} \mathrm{l}^{-1}, \mathrm{~F}_{4}$ (NSKE) @ 5\% and $\mathrm{F}_{5}$ (Neem formulation) @ $2.5 \mathrm{mll}^{-1}$ and $\mathrm{F}_{6}$ i.e. control (without any spray).

The observations were recorded from five randomly selected plants from every plot of each treatment. The observations included number of seeds fruit ${ }^{-1}$, thousand seed weight (g), seed yield plant ${ }^{-1}(\mathrm{~g})$, seed yield plot $^{-1}(\mathrm{~g})$, seed yield ha-1 $(\mathrm{kg})$ and also the benefit: cost ratio was worked out. The statistical analysis of the data recorded was done as per design of the experiment as suggested by Gomez and Gomez (1984).

\section{Results and Discussion}

The seed yield is the ultimate goal of any seed producer and can be achieved by growing healthy and insect pest free plants. The insect pests hamper the growth and development of plants by utilizing the metabolites necessary for fruit and seed development and thus affect the seed yield adversely. The number of seeds fruit ${ }^{-1}$ is an important attribute of the final seed yield which is influenced by fruit size and healthy growth of the plants. The data recorded as influenced by seed treatment, soil application, foliar spray and their interaction for different treatments is presented in Table 1. The number of seeds fruit $^{-1}$ differed significantly due to seed and soil treatments. Seed treatment with thiamethoxam $\left(\mathrm{S}_{2}\right)$ recorded significantly higher number of seeds fruit ${ }^{-1}$ (182.21) followed by seed treatment with imidacloprid $\left(\mathrm{S}_{1}\right)$ 179.85, soil application neem cake $\left(\mathrm{S}_{3}\right) 176.60$ and soil application of carbofuran $\left(\mathrm{S}_{4}\right)$ 173.92. Foliar spray with thiamethoxam $\left(\mathrm{F}_{2}\right)$ recorded significantly higher number of seeds fruit ${ }^{-1}$ (186.54) followed by imidacloprid $\left(F_{1}\right)$ recording 182.62 number of seeds fruit ${ }^{-1}$. Control $\left(F_{6}\right)$ recorded minimum (170.28) number of seeds fruit ${ }^{-1}$. The treatment combination viz., seed treatment and foliar spray of thiamethoxam $\left(\mathrm{S}_{2} \mathrm{~F}_{2}\right)$ recorded significantly higher number of seeds fruit ${ }^{-1}$ (190.66) whereas minimum number of seeds fruit $^{-1}$ (166.24) was observed in soil application with carbofuran without any foliar spray $\left(\mathrm{S}_{4} \mathrm{~F}_{6}\right)$. The reason behind this may be that insect pest free plants produced larger sized fruits and and size of fruit is correlated to number of seeds (Kinet and Peet, 1997). The findings are in agreement with Sajjan and Praveen (2008) who recorded highest number of seeds per fruits at harvest by using imidacloprid @ $12 \mathrm{ml}$ per kg seed or thiamethoxam @ 10g per kg seed.

Thousand seed weight or test weight determines the final seed yield. Seed treatment with thiamethoxam $\left(\mathrm{S}_{2}\right)$ recorded significantly higher thousand seed weight (5.43 g) followed by seed treatment with imidacloprid $\left(\mathrm{S}_{1}\right) 5.38 \mathrm{~g}$. soil application neem cake $\left(\mathrm{S}_{3}\right) 5.31 \mathrm{~g}$ and soil application of carbofuran $\left(\mathrm{S}_{4}\right)$ $5.24 \mathrm{~g}$. Whereas foliar spray with thiamethoxam $\left(\mathrm{F}_{2}\right)$ recorded significantly higher thousand seed weight (5.49 g) followed by imidacloprid $\left(F_{2}\right)$ recording $5.44 \mathrm{~g}$ thousand seed weight. The interaction between seed treatment and foliar spray of thiamethoxam $\left(\mathrm{S}_{2} \mathrm{~F}_{2}\right)$ resulted in significantly higher thousand seed weight ( $5.58 \mathrm{~g}$ ). This might be due to the photosynthates produced by the plants were not utilized by insect pests which resulted in well filled and bold seeds having more test weight. The results are in conformity with Sajjan and Praveen (2008) who reported higher 100 seed weight at harvest by using imidacloprid @ $12 \mathrm{ml} \mathrm{kg}^{-1}$ seed or thiamethoxam @ 10 g per kg seed.

Seed yield per plant determines the seed yield per $\mathrm{m}^{2}$ which further determines the net profitability. Seed yield per plant differed significantly due to seed and soil treatments. Seed treatment with thiamethoxam $\left(\mathrm{S}_{2}\right)$ recorded significantly higher seed yield per plant (16.62 g) followed by seed treatment with imidacloprid $\left(\mathrm{S}_{1}\right) 15.70 \mathrm{~g}$, soil treatment neem cake $\left(\mathrm{S}_{3}\right) 15.47 \mathrm{~g}$ and soil treatment carbofuran $\left(\mathrm{S}_{4}\right) 14.85 \mathrm{~g}$. Foliar spray with thiamethoxam $\left(F_{2}\right)$ recorded significantly 


\begin{tabular}{|c|c|c|c|c|c|c|c|c|c|c|c|c|c|c|c|c|}
\hline \multirow[t]{3}{*}{ FA } & \multirow[t]{3}{*}{ Dose } & \multicolumn{4}{|c|}{ No. of seeds fruit ${ }^{-1}$} & \multirow[t]{3}{*}{$M$} & \multicolumn{4}{|c|}{$\begin{array}{l}\text { Thousand seed weight } \\
\text { (g) }\end{array}$} & \multirow[t]{3}{*}{$\mathrm{M}$} & \multicolumn{4}{|c|}{ Seed yield plant ${ }^{-1}(\mathrm{~g})$} & \multirow[t]{3}{*}{ M } \\
\hline & & \multicolumn{2}{|c|}{$\begin{array}{l}\text { Seed } \\
\text { treatment }\end{array}$} & \multicolumn{2}{|c|}{$\begin{array}{c}\text { Soil } \\
\text { application }\end{array}$} & & \multicolumn{2}{|c|}{$\begin{array}{l}\text { Seed } \\
\text { treatment }\end{array}$} & \multicolumn{2}{|c|}{$\begin{array}{l}\text { Soil } \\
\text { applica- } \\
\text { tion }\end{array}$} & & \multicolumn{2}{|c|}{$\begin{array}{l}\text { Seed } \\
\text { treatment }\end{array}$} & \multicolumn{2}{|c|}{$\begin{array}{c}\text { Soil } \\
\text { application }\end{array}$} & \\
\hline & & ${ }^{* *} S_{1}$ & $\mathrm{~S}_{2}$ & $\mathrm{~S}_{3}$ & $\mathrm{~S}_{4}$ & & ${ }^{* *} S_{1}$ & $\mathrm{~S}_{2}$ & $\mathrm{~S}_{3}$ & $\mathrm{~S}_{4}$ & & ${ }^{* *} S_{1}$ & $\mathrm{~S}_{2}$ & $\mathrm{~S}_{3}$ & $\mathrm{~S}_{4}$ & \\
\hline${ }^{*} \mathrm{~F}_{1}$ & $\begin{array}{l}0.5 \\
\mathrm{mll}^{-1}\end{array}$ & 184.97 & 186.11 & 180.66 & 178.75 & 182.62 & 5.46 & 5.52 & 5.41 & 5.38 & 5.44 & 16.09 & 18.62 & 15.93 & 15.75 & 16.6 \\
\hline $\mathrm{F}_{2}$ & $\begin{array}{l}0.40 \\
\mathrm{~g} \mathrm{l}^{-1}\end{array}$ & 187.86 & 190.66 & 185.37 & 182.29 & 186.54 & 5.5 & 5.58 & 5.46 & 5.41 & 5.49 & 16.57 & 18.91 & 16.2 & 16.01 & 16.92 \\
\hline $\mathrm{F}_{3}$ & $\begin{array}{l}0.5 \\
\mathrm{mll}^{-1}\end{array}$ & 175.23 & 178.46 & 172.34 & 170.23 & 174.06 & 5.37 & 5.39 & 5.31 & 5.07 & 5.28 & 14.84 & 14.97 & 14.72 & 14.45 & 14.75 \\
\hline $\mathrm{F}_{4}$ & $5 \%$ & 180.53 & 182.36 & 176.43 & 173.65 & 178.24 & 5.4 & 5.46 & 5.36 & 5.31 & 5.38 & 15.86 & 16.15 & 15.45 & 15.32 & 15.69 \\
\hline $\mathrm{F}_{5}$ & $\begin{array}{l}2.5 \\
\mathrm{ml} \mathrm{l}^{-1}\end{array}$ & 178.51 & 181.32 & 176.3 & 172.36 & 177.12 & 5.38 & 5.41 & 5.34 & 5.28 & 5.35 & 15.6 & 15.72 & 15.45 & 15.12 & 15.47 \\
\hline $\mathrm{F}_{6}$ & & 172.03 & 174.34 & 168.52 & 166.24 & 170.28 & 5.14 & 5.21 & 5.02 & 4.98 & 5.09 & 15.27 & 15.35 & 15.04 & 12.44 & 14.52 \\
\hline$M$ & & 179.85 & 182.21 & 176.6 & 173.92 & 178.15 & 5.38 & 5.43 & 5.31 & 5.24 & 5.34 & 15.7 & 16.62 & 15.47 & 14.85 & 15.66 \\
\hline \multicolumn{17}{|l|}{$C D$} \\
\hline $\mathrm{F}$ & & & & & & 0.76 & & & & & 0.01 & & & & & 0.1 \\
\hline$S$ & & & & & & 0.62 & & & & & 0.01 & & & & & 0.08 \\
\hline $\mathrm{F} \times \mathrm{S}$ & & & & & & 0.54 & & & & & 0.02 & & & & & 0.21 \\
\hline
\end{tabular}

Table 1: Continue...

\begin{tabular}{|c|c|c|c|c|c|c|c|c|c|c|c|}
\hline \multirow[t]{3}{*}{ FA } & \multirow[t]{3}{*}{ Dose } & \multicolumn{4}{|c|}{ Seed yield plot $^{-1}(\mathrm{~g})$} & & \multicolumn{4}{|c|}{ Seed yield ha ${ }^{-1}(\mathrm{~kg})$} & \multirow[t]{3}{*}{ Mean } \\
\hline & & \multicolumn{2}{|c|}{$\begin{array}{c}\text { Seed } \\
\text { treatment }\end{array}$} & \multicolumn{2}{|c|}{$\begin{array}{c}\text { Soil } \\
\text { application }\end{array}$} & \multirow[t]{2}{*}{ Mean } & \multicolumn{2}{|c|}{$\begin{array}{l}\text { Seed } \\
\text { treatment }\end{array}$} & \multicolumn{2}{|c|}{$\begin{array}{c}\text { Soil } \\
\text { application }\end{array}$} & \\
\hline & & ${ }^{* *} S_{1}$ & $\mathrm{~S}_{2}$ & $\mathrm{~S}_{3}$ & $\mathrm{~S}_{4}$ & & ${ }^{* *} \mathrm{~S}_{1}$ & $\mathrm{~S}_{2}$ & $\mathrm{~S}_{3}$ & $\mathrm{~S}_{4}$ & \\
\hline${ }^{*} \mathrm{~F}_{1}$ & $0.5 \mathrm{mll}^{-1}$ & 368.17 & 371.5 & 365.42 & 360.32 & 366.36 & 681.8 & 687.97 & 676.7 & 667.27 & 678.44 \\
\hline $\mathrm{F}_{2}$ & $0.40 \mathrm{~g} \mathrm{l}^{-1}$ & 372 & 385.81 & 369.38 & 367.67 & 373.7 & 688.9 & 714.46 & 684.04 & 680.87 & 692.07 \\
\hline $\mathrm{F}_{3}$ & $0.5 \mathrm{mll}^{-1}$ & 352.39 & 356.25 & 344.36 & 338.68 & 347.92 & 652.57 & 659.72 & 637.7 & 627.19 & 644.3 \\
\hline $\mathrm{F}_{4}$ & $5 \%$ & 363.05 & 364.99 & 355.78 & 348.46 & 358.07 & 672.31 & 675.9 & 658.86 & 645.29 & 663.09 \\
\hline $\mathrm{F}_{5}$ & $2.5 \mathrm{ml} \mathrm{l}^{-1}$ & 358.92 & 361.25 & 350.05 & 342.92 & 353.28 & 664.66 & 668.98 & 648.24 & 635.03 & 654.23 \\
\hline $\mathrm{F}_{6}$ & & 298.29 & 312.51 & 283.33 & 273.3 & 291.88 & 552.38 & 578.72 & 524.69 & 506.28 & 540.52 \\
\hline M & & 352.14 & 358.72 & 344.72 & 338.57 & 348.54 & 652.1 & 664.29 & 638.37 & 626.99 & 645.44 \\
\hline \multicolumn{12}{|l|}{$C D$} \\
\hline $\mathrm{F}$ & & & & & & 1.16 & & & & & 2.14 \\
\hline$S$ & & & & & & 0.95 & & & & & 1.75 \\
\hline $\mathrm{F} \times \mathrm{S}$ & & & & & & 2.33 & & & & & 4.32 \\
\hline
\end{tabular}

${ }^{*} \mathrm{~F}_{1}$ : Imidacloprid (confiders); $\mathrm{F}_{2}$ : Thiamethoxam (Actara); $\mathrm{F}_{3}$ : Indoxacarb (Avaunt); $\mathrm{F}_{4}$ : NSKE (neem seed kernel extract); $\mathrm{F}_{5}$ : Neem (Raj Neem) formulation; $\mathrm{F}_{6}$ : Control; M: Mean; CD: CD ( $\left.p=0.05\right)$; *Foliar spray (F); ** Seed Treatment ( $\mathrm{S}_{1}$ ) Imidacloprid (Gaucho 600 FS); S $_{2}$ : Thiamethoxam (Cruiser 70WS) and Soil Application; S: Neem Cake; S: Carbofuran (Furadon 3G)

higher seed yield per plant (16.92 g) followed by imidacloprid

$\left(F_{1}\right)$ recording $16.60 \mathrm{~g}$ seed yield plant ${ }^{-1}$ whereas control

$\left(F_{6}\right)$ recorded minimum $(14.52 \mathrm{~g})$ seed yield per plant. The treatment combination viz., seed treatment and foliar spray of thiamethoxam $\left(\mathrm{S}_{2} \mathrm{~F}_{2}\right)$ recorded significantly higher seed yield plant ${ }^{-1}(18.91 \mathrm{~g})$. The healthy plants gave large sized and more number of fruits which resulted in higher seed yields plant $^{-1}$. Seed yield plot ${ }^{-1}$ also differed significantly due to seed 
and soil treatments. Seed treatment with thiamethoxam $\left(\mathrm{S}_{2}\right)$ recorded significantly higher seed yield per plot (358.72 g). Followed by the seed treatment with imidacloprid $\left(S_{1}\right)$ $352.14 \mathrm{~g}$, soil application of neem cake $\left(\mathrm{S}_{3}\right) 344.72 \mathrm{~g}$ and soil application of carbofuran $\left(\mathrm{S}_{4}\right) 338.57 \mathrm{~g}$. Whereas, foliar spray with thiamethoxam $\left(F_{2}\right)$ recorded significantly higher seed yield per plot ( $373.70 \mathrm{~g}$ ) followed by imidacloprid $\left(F_{1}\right) 366.36$ g. The interaction between seed treatment and foliar spray of thiamethoxam $\left(\mathrm{S}_{2} \mathrm{~F}_{2}\right)$ resulted in significantly higher seed yield per plot ( $385.81 \mathrm{~g})$. These results are in conformity with the earlier reports of various workers who reported that seed treatment and subsequent foliar spray of thiamethoxam and imidacloprid significantly higher yield of okra, cotton and other crops (Mahal et al., 1994; Krishnakumar et al., 2001; Rathod et al., 2003; Meena et al., 2007).

Higher seed yield ha-1 shows the net returns of the farmers or seed producers. Well managed and insect pest free agricultural land results in higher outputs which gives higher returns. Seed treatment with thiamethoxam $\left(\mathrm{S}_{2}\right)$ recorded significantly higher seed yield ha-1 (kg) 664.29 kg, followed by seed treatment with imidacloprid $\left(\mathrm{S}_{1}\right) 652.10 \mathrm{~kg}$, soil application of neem cake $\left(\mathrm{S}_{3}\right) 638.37 \mathrm{~kg}$ and soil application of carbofuran $\left(\mathrm{S}_{4}\right) 626.99 \mathrm{~kg}$. Foliar spray with thiamethoxam $\left(F_{2}\right)$ recorded significantly higher seed yield ha-1 $(\mathrm{kg}) 678.44$ $\mathrm{kg}$. Next best treatment was imidacloprid $\left(\mathrm{F}_{1}\right)$ recording seed yield per ha $(\mathrm{kg}) 692.07 \mathrm{~kg}$. The treatment combination viz., seed treatment and foliar spray of thiamethoxam $\left(\mathrm{S}_{2} \mathrm{~F}_{2}\right)$ resulted significantly higher seed yield ha-1 $(\mathrm{kg}) 714.46 \mathrm{~kg}$. The insecticides used, efficiently controlled the insect pests of bell pepper which resulted in good growth throughout the growing season and in turns gave the higher seed yields. The benefit: cost ratio also varies in the similar fashion as that of yield as indicated in the Table 2 . In the present investigation, maximum B: C ratio of 4.52:1 was obtained with combination seed treatment and foliar spray of thiamethoxam $\left(\mathrm{S}_{2} \mathrm{~F}_{2}\right)$ followed by soil treatment with carbofuran and foliar spray

Table 2: Effect of seed treatment, soil application and foliar spray on benefit: cost ratio in seed production of Bell pepper cv. Solan Bharpur

\begin{tabular}{|c|c|c|c|c|c|c|c|}
\hline & $\begin{array}{l}\text { Variable } \\
\text { cost (₹) }\end{array}$ & $\begin{array}{l}\text { Fixed cost } \\
(₹)\end{array}$ & $\begin{array}{l}\text { Total cost of } \\
\text { cultivation (₹) }\end{array}$ & $\begin{array}{c}\text { Seed yield ha-1 } \\
(\mathrm{kg})\end{array}$ & $\begin{array}{c}\text { Gross returns } \\
\text { (₹) }\end{array}$ & $\begin{array}{l}\text { Net returns } \\
(₹)\end{array}$ & $\mathrm{B}: \mathrm{C}$ ratio \\
\hline $\mathrm{S}_{1} \mathrm{~F}_{1}$ & 2606.59 & 252801.70 & 255408.29 & 681.80 & 1363604.94 & 1108196.65 & 4.34:1 \\
\hline $\mathrm{S}_{1} \mathrm{~F}_{2}$ & 5939.93 & 252801.70 & 258741.63 & 688.90 & 1377790.12 & 1119048.50 & $4.32: 1$ \\
\hline $\mathrm{S}_{1} \mathrm{~F}_{3}$ & 662.15 & 252801.70 & 253463.85 & 652.57 & 1305148.15 & 1051684.30 & $4.15: 1$ \\
\hline $\mathrm{S}_{1} \mathrm{~F}_{4}$ & 569.56 & 252801.70 & 253371.26 & 672.31 & 1344629.63 & 1091258.37 & 4.31:1 \\
\hline $\mathrm{S}_{1} \mathrm{~F}_{5}$ & 3254.74 & 252801.70 & 256056.44 & 664.66 & 1329320.99 & 1073264.55 & 4.19:1 \\
\hline $\mathrm{S}_{1} \mathrm{~F}_{6}$ & 14.00 & 252801.70 & 252815.70 & 552.38 & 1104765.43 & 851949.73 & $3.37: 1$ \\
\hline $\mathrm{S}_{2} \mathrm{~F}_{1}$ & 2628.59 & 252801.70 & 255430.29 & 687.97 & 1375938.27 & 1120507.98 & 4.39:1 \\
\hline $\mathrm{S}_{2} \mathrm{~F}_{2}$ & 5961.93 & 252801.70 & 258763.63 & 714.46 & 1428925.93 & 1170162.30 & $4.52: 1$ \\
\hline $\mathrm{S}_{2} \mathrm{~F}_{3}$ & 684.15 & 252801.70 & 253485.85 & 659.72 & 1319444.44 & 1065958.60 & $4.21: 1$ \\
\hline $\mathrm{S}_{2} \mathrm{~F}_{4}$ & 591.56 & 252801.70 & 253393.26 & 675.90 & 1351802.47 & 1098409.21 & 4.33:1 \\
\hline $\mathrm{S}_{2} \mathrm{~F}_{5}$ & 3276.74 & 252801.70 & 256078.44 & 668.98 & 1337962.96 & 1081884.52 & $4.22: 1$ \\
\hline $\mathrm{S}_{2} \mathrm{~F}_{6}$ & 36.00 & 252801.70 & 252837.70 & 578.72 & 1157432.10 & 904594.40 & $3.58: 1$ \\
\hline $\mathrm{S}_{3} \mathrm{~F}_{1}$ & 9508.59 & 252801.70 & 262310.29 & 676.70 & 1353407.41 & 1091097.11 & $4.16: 1$ \\
\hline $\mathrm{S}_{3} \mathrm{~F}_{2}$ & 12841.93 & 252801.70 & 265643.63 & 684.04 & 1368086.42 & 1102442.79 & $4.15: 1$ \\
\hline $\mathrm{S}_{3} \mathrm{~F}_{3}$ & 7564.15 & 252801.70 & 260365.85 & 637.70 & 1275407.41 & 1015041.56 & 3.90:1 \\
\hline $\mathrm{S}_{3} \mathrm{~F}_{4}$ & 7471.56 & 252801.70 & 260273.26 & 658.86 & 1317716.05 & 1057442.79 & 4.06:1 \\
\hline $\mathrm{S}_{3} \mathrm{~F}_{5}$ & 10156.74 & 252801.70 & 262958.44 & 648.24 & 1296481.48 & 1033523.04 & 3.93:1 \\
\hline $\mathrm{S}_{3} \mathrm{~F}_{6}$ & 6916.00 & 252801.70 & 259717.70 & 524.69 & 1049382.72 & 789665.02 & $3.04: 1$ \\
\hline $\mathrm{S}_{4} \mathrm{~F}_{1}$ & 4074.59 & 252801.70 & 256876.29 & 667.27 & 1334530.86 & 1077654.57 & $4.20: 1$ \\
\hline $\mathrm{S}_{4} \mathrm{~F}_{2}$ & 7407.93 & 252801.70 & 260209.63 & 680.87 & 1361740.74 & 1101531.11 & $4.23: 1$ \\
\hline $\mathrm{S}_{4} \mathrm{~F}_{3}$ & 2130.15 & 252801.70 & 254931.85 & 627.19 & 1254370.37 & 999438.52 & $3.92: 1$ \\
\hline $\mathrm{S}_{4} \mathrm{~F}_{4}$ & 2037.56 & 252801.70 & 254839.26 & 645.29 & 1290580.25 & 1035740.99 & 4.06:1 \\
\hline $\mathrm{S}_{4} \mathrm{~F}_{5}$ & 4722.74 & 252801.70 & 257524.44 & 635.03 & 1270061.73 & 1012537.29 & 3.93:1 \\
\hline $\mathrm{S}_{4} \mathrm{~F}_{6}$ & 1482.00 & 252801.70 & 254283.70 & 506.28 & 1012555.56 & 758271.86 & 2.98:1 \\
\hline
\end{tabular}


with thiamethoxam $\mathrm{S}_{4} \mathrm{~F}_{2}$ i.e. 4.23:1 whereas, minimum $\mathrm{B}: \mathrm{C}$ ratio (2.29:1) was resulted from the seed treatment with imidacloprid with no foliar spray $\left(\mathrm{S}_{4} \mathrm{~F}_{6}\right)$. Sajjan and Praveen (2008) revealed that seed treatment with imidacloprid @ 12 ml kg-1 seed or thiamethoxam @ 10 g per kg seed was effective in controlling leaf hoppers and resulted higher seed yield ha-1.

\section{Conclusion}

Seed treatment with thiomethoxam (Cruiser) @ 10 g per kg seed and two foliar sprays of thiomethoxam (Actara), first spray after thirty days of transplanting and second spray after fifteen days of first spray, were found effective in controlling insect pests and resulted in higher seed yield in bell pepper.

\section{References}

Agarwal, A., Gupta, S., Ahmed, Z., 2007. Influence of plant densities on productivity of bell pepper (Capsicum annuum L.) under greenhouse in high altitude cold desert of Ladakh. Acta Horticulture 756, 309-314.

Brandt, K., Mabgaard, 2001. Organic agriculture does it enhance or reduce the nutritional value of plant foods. Journal of Science Food Agriculture 81(4), 924-931.

Bukasov, S.M., 1930. The cultivated plants of Mexico, Guatemala and Columbia. Bulletin of Applied Botany Genetics and Plant Breeding 47, 261-273.

Gomez, K.A., Gomez, A.A., 1984. Statical procedure for agricultural research. John Wily and Sons, New York, 690.

Kinet, J.M., Peet, M.M., 1997. The Physiology of Vegetable Crops. Wien, H.C. (Ed.), CAB International, UK, 207-257.
Kirshnakumar, N.K., Krishnamoorthy, P.N., Eswara Reddy, S.G., 2001. Imidaeloprid and thiomethoxam for the control of okra leaf hopper. Amrasca biguttula biguttula (Ishida). Pest Management in Horticultural Ecosystems 7(2), 117-123.

Mahal, M.S., Brar, L.S., Jawantsingh, 1994. Effect of variable feedin exposures to jassid Amrasca biguttula (Ishida) on okra seed yield of okra. Journal of Insect Science 7(2), 125-128.

Meena, R., Gupta, H.C.L., Swaminathan, R., 2007. Field efficacy of some newer insecticides against coriander aphid (Hyada phiscoriandari DAS). Pestoiogy 33(7), 32-36.

Rathod, K.S., Lavelkar, R.C., Pande, A.K., Patanage, N.R., Sharma, O.P., 2003. Efficacy of imidaeloprid against sucking pests of cotton. Annals of Plant Protection Sciences 11(2), 369-370.

Sajjan, S.A., Praveen, P.K., 2008. Studiesh on leaf hopper and fruit borer management as influeneed by seed treatment and foliar spray in Bhendi (Abelmoschus esculentus L. moench) seed production. Agricultural science digest 28(3), 170-173.

Smith, P.G., Heiser, C.B., 1957. Breeding behaviour of cultivated peppers. Proceedings of American Society of Horticulture Science 10, 286-290.

Vyrodova, A.P., Andryschenko, V.K., Zatuliverter. V.I., 1988. Content of beta carotene in various vegetables. Physiology and Biochemistry of Cultivated Plants 20, 167-171. 